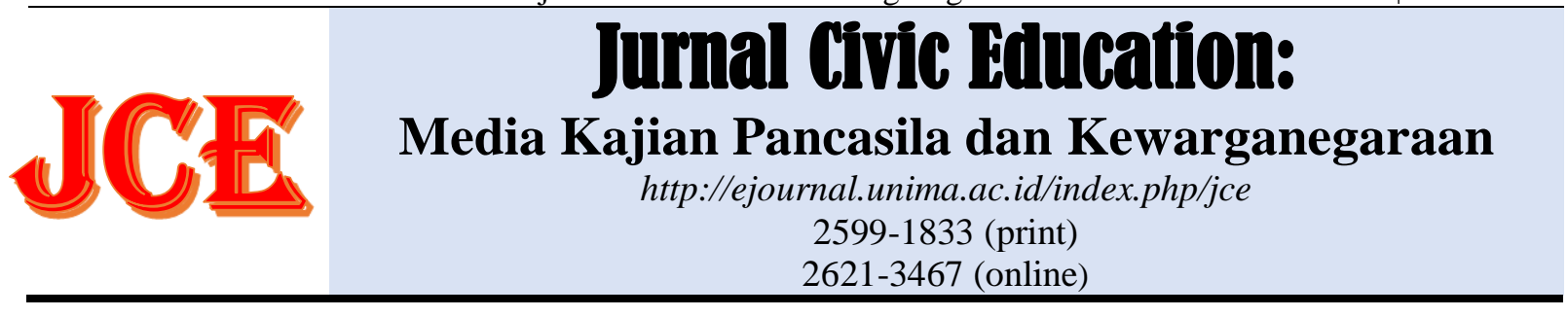

\title{
Kajian Nilai Ketuhanan Yang Maha Esa untuk Mengembangkan Karakter Anti Korupsi
}

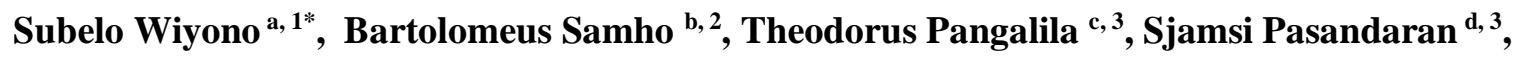 \\ ${ }^{a}$ Universitas Pasundan, Bandung, Indonesia \\ ${ }^{\mathrm{b}}$ Universitas Parahyangan, Bandung, Indonesia \\ ${ }^{\mathrm{c}}$ Universitas Negeri Manado \\ d Universitas Negeri Manado \\ * subelo.wiyono@unpas.ac.id
}

\begin{tabular}{ll}
\hline \multicolumn{2}{l}{ Informasi artikel } \\
\hline Sejarah artikel: \\
Diterima & $: 20-10-2019$ \\
Revisi & $: 10-11-2019$ \\
Dipublikasikan & $: 2-12-2019$ \\
\hline
\end{tabular}

Kata kunci:

Pancasila

Ketuhanan Yang Maha Esa

Pendidikan Anti Korupsi

\begin{abstract}
ABSTRAK
Negara Republik Indonesia adalah negara hukum berdasarkan Pancasila Salah satu bagian penting dari materi pendidikan anti korupsi di Indonesia adalah pemahaman nilai-nilai Pancasila. Berbagai sumber menunjukkan masih kurangnya penelitian Pendidikan Anti Korupsi berbasis Pancasila. Sila pertama Pancasila yang menjiwai keempat sila berikutnya menjadi sentral penelitian awal ini. Perguruan tinggi memiliki posisi strategis untuk memenuhi harapan peneliti dalam peranannya sebagai pendorong efektivitas pemberantasan tindak pidana korupsi. Berkaitan dengan gagasan-gagasan tersebut, penelitian ini menggunakan pendekatan qualitative research dengan model grounded. Teknik pengumpulan data akan peneliti lakukan dengan studi dokumen, wawancara, dan observasi. Sumber dokumen adalah dokumen formal, literatur, buku teks, dan perangkat pembelajaran. Informan adalah pakar di bidang filsafat, Pendidikan Kewarganegaraan, dan dosen. Observasi dilakukan terhadap proses pembelajaran Pancasila oleh dosen di perguruan tinggi. Analisis data menggunakan model induktif. Akan tetapi dalam bagian (artikel) ini peneliti masih sebatas menggunakan studi pustaka sebagai awal penelitian yang lebih besar. Penelitian awal yang akan dituangan dalam artikel ini memberikan gambaran bagaimana persoalan yang dihadapi bangsa Indonesia dan peluang yang bisa dijadikan celah untuk menyelesaikannya. Telaah terhadap nilai Ketuhanan Yang Maha Esa peneliti anggap cukup strategis menjadi bagian awal penelitian yang lebih besar.
\end{abstract}

Keywords:
Pancasila
Belief in the one Almighty God
Anti-corruption education

Keywords:

Anti-corruption education

\section{ABSTRACT}

The problem of corruption in Indonesia is getting more rampant. The convicted are not people who do not realize and understand Pancasila. They are people who had taken higher level degree in education. However, the degree itself is not a guarantee for one's awareness of being honest and obedient to the law. Why cognitive intelligence could not prevent these people to do corruption? Mostly, corruption is hard to overcome. However, the researchers regard Pancasila as a power that would prevent and overcome the corruption tendency. Pancasila contains potential values for the formation of anti-corruption mentality. For example, the values contained in Pancasila, especially the first principle; "Belief in the One, Almighty God". Related to that, in studying the first principle, the intended study would apply grounded theory model within a qualitative paradigm that will be concluded later as part of a large-scale study. Therefore, this study would only provide a literature study such as some formal documents, literatures, textbooks, and learning media, as a part of finding a support for the upcoming study. Later, the large-scale study will provide various data collection that would entail this study as previous finding from a literature study perspective. 


\section{Pendahuluan}

Negara Republik Indonesia adalah negara hukum berdasarkan Pancasila dan Undang-undang Dasar 1945 yang menjujung tinggi hak asasi manusia serta menjamin segala warga negara bersamaan kedudukannya di dalam hukum dan pemerintahan dan wajib menjunjung hukum dan pemerintahan itu tanpa terkecuali (Karjadi, 1981).

Suatu negara hukum menurut Friedrich Julius Stahl dalam bukunya Jimly Asshiddiqie yang berjudul, "Konstitusi dan Konstitusionalisme Indonesia", harus memiliki empat unsur pokok, yaitu: (a). pengakuan dan perlindungan terhadap hak asasi manusia; (b). negara didasarkan pada teori trias politica; (c). pemerintahan didasarkan pada undang-undang (wetmatig bestuur); ada peradilan administrasi negara yang bertugas menangani kasus perbuatan melanggar hukum oleh pemerintah (onrechtmatige overheidsdaad) (Asshiddiqie, 2006).

Menurut Sri Soemantri negara hukum harus memenuhi unsur, yaitu (Soemantri, 1992): (a). pemerintah dalam melaksanakan tugas dan kewajibannya harus berdasar atas hukum atau peraturan perundangundangan; (b). adanya jaminan terhadap hakhak asasi manusia (warga negara); (c). adanya pembagian kekuasaan dalam negara; (d). adanya pengawasan dari badan-badan peradilan.

Atas dasar ciri-ciri negara hukum yang dikemukakan oleh beberapa para pakar hukum tersebut menunjukkan bahwa adanya pengakuan dan perlindungan terhadap hak asasi manusia yang bertumpu pada prinsip kebebasan dan persamaan di depan hukum (equality before the law).

Hukum dengan tegas telah mengatur perbuatan-perbuatan manusia yang bersifat lahiriyah, dan hukum mempunyai sifat untuk menciptakan keseimbangan antara kepentingan para warga masyarakat. Dengan demikian hukum mempunyai sifat memaksa dan mengikat, walaupun unsur paksaan bukanlah merupakan unsur yang terpenting dalam hukum, sebab tidak semua perbuatan atau larangan dapat dipaksakan. Dalam hal ini, memaksakan diartikan sebagai suatu perintah yang ada sanksinya apabila tidak ditaati, dan sanksi tersebut berwujud sebagai suatu penderitaan yang dapat memberikan penjeraan bagi si pelanggar hukum.
Lahirnya Undang-undang Nomor 8 Tahun 1981 tentang Kitab Undang-undang Hukum Acara Pidana (KUHAP), merupakan era baru dalam dunia peradilan di Indonesia. Selain merupakan produk nasional yang menggantikan hukum ciptaan kolonial, juga memberikan spesialisasi, differensiasi dan kompartemenisasi dalam pelaksanaan penegakan hukum yang mengandung koordinasi dalam pelaksanaan tugas tersebut.

KUHAP sebagai landasan hukum peradilan pidana, membawa konsekwensi bahwa alat negara dalam menjalankan tugasnya dituntut untuk meninggalkan cara lama secara keseluruhan, baik dalam berfikir, maupun dalam bersikap, harus sesuai dengan undangundang yang berlaku, dan mejunjung tinggi hak asasi manusia, terutama mereka yang tersangkut dalam peradilan pidana yang mengharuskan penegak hukum melakukan tindakan paksa. Upaya paksa dapat dikemukakan di sini adalah sebagaimana tercantum dalam KUHAP BAB V Bagian Kesatu tentang Penangkapan (Pasal 16-19), Bagian Kedua tentang Penahanan (Pasal 2031), Bagian Ketiga tentang Penggeledahan (Pasal 32-37), Bagian Keempat tentang Penyitaan (Pasal 38-46), Bagian Kelima tentang Pemeriksaan Surat (Pasal 47-49). Namun secara spesifik penulis hanya membahas tentang upaya paksa mengenai penangkapan dan penahan yang dilakukan penyidik Polri.

Namun harus diingat pula bahwa aparat penegak hukum adalah manusia biasa yang tidak terlepas dari perbuatan khilaf dan salah, upaya paksa yang sesungguhnya sudah merupakan suatu nestapa bagi tersangka ternyata masih ditemukan kejadian-kejadian yang cenderung tidak sesuai dengan apa yang digariskan undang-undang. Penegak hukum dalam hal ini Polri sebagai penyidik di dalam melakukan tindakan upaya paksa masih sering melakukan tindakan-tindakan kekerasan fisik sehingga menimbulkan penderitaan bagi tersangka.

Sesungguhnya hal ini tidak perlu terjadi apabila penegak hukum dalam hal ini polisi dalam bertindak, lebih memahami serta menghayati dan menjunjung tinggi hak asasi manusia seperti diamanatkan dalam Pancasila dan UUD 1945 dan menjunjung tinggi asas praduga tak bersalah.

Sebagaimana ketentuan pokok Konvensi Internasional yang Menentang Penyiksaan dan Perlakuan atau Penghukuman Lain yang 
Kejam, Tidak Manusiawi, atau Merendahkan Martabat Manusia International Convention Against Torture and Other, Cruel, Inhuman or Degrading Treatment or Punishment (selanjutnya disingkat Konvensi Anti Penyiksaan), telah diatur pelarangan penyiksaan baik fisik maupun mental dan perlakuan atau penghukuman lain yang kejam, tidak manusiawi, atau merendahkan maratabat manusia yang dilakukan oleh atau atas hasutan dari atau dengan persetujuan/sepengetahuan pejabat publik dan orang lain yang bertindak dalam jabatannya.

Penangkapan dan penahanan yang sebetulnya dilakukan dengan tujuan untuk kepentingan pemeriksaan demi tegaknya keadilan dan ketertiban dalam masyarakat, ternyata masih ditemukan tindakan penegak hukum yang menyimpang dari KUHAP, bahwa masih ada beberapa kekurangan atau penyimpangan yang berkait dengan perlindungan hak asasi manusia (HAM) tersangka dalam proses penyidikan, sehingga tersangka menderita lahir batin akibat sikap tindak para aparat penegak hukum tersebut dan sudah tentu ini merupakan pelanggaran HAM.

Untuk menjamin perlindungan HAM dan agar aparat penegak hukum menjalankan tugasnya secara konsekuen khususnya dalam melaksanakan upaya paksa, maka KUHAP telah mengaturnya sehingga penyidik, penuntut umum tidak lagi semaunya bertindak yang pada akhirnya akan melanggar hak-hak tersangka seperti memperlakukan tersangka secara kejam yang menyebabkan menurunnya harkat dan martabat manusia/tersangka. Hal-hal yang diuraikan tersebut menarik untuk diteliti yang dituangkan dalam bentuk penelitian yang berjudul: "Kajian Hukum ratifikasi Konvensi Internasional yang Menentang Penyiksaan dikaitkan dengan pelaksanaan upaya paksa Menurut Kitab Undang-Undang Hukum Acara Pidana (KUHAP)".

Sejalan dengan latar belakang di atas, terdapat permasalahan yang timbul dimana penulis merumuskannya sebagai berikut:

"Bagaimana ratifikasi konvensi Internasional yang menentang penyiksaan dikaitkan dengan pelaksanaan upaya paksa menurut Kitab Undang-Undang Hukum Acara Pidana (KUHAP)?"

\section{Metode}

Penelitian hukum merupakan suatu kegiatan ilmiah yang didasarkan pada metode sistematika dan suatu pemikiran tertentu yang bertujuan untuk mempelajari satu atau beberapa gejala hukum tertentu, dengan jalan menganalisanya (Soekanto, 1986).

Menurut Soerjono Soekanto mengemukakan bahwa metodologi penelitian adalah:

1. Suatu tipe pemikiran yang dipergunakan dalam penelitian dan penilaian

2. Suatu teknik yang umum bagi ilmu pengetahuan

3. Cara tertentu untuk melakukan prosedur.

Oleh sebab itu, metodologi penelitian sebagai unsur yang penting dan agar data yang diperoleh benar-benar akurat agar penulisan hukum ini dapat dipertanggung jawabkan kebenarannya.

Dalam penelitian ini digunakan jenis penelitian normatif dengan data sekunder yang terdiri dari bahan hukum primer, yaitu bahanbahan hukum yang mengikat yang terdiri dari peraturan perundang-undangan yang digunakan adalah peraturan perundang-undangan yang berkorelasi dengan topik penelitian bahan hukum sekunder yang memberikan penjelasan mengenai bahan hukum primer seperti buku, majalah, artikel, makalah dalam seminar yang berkaitan dengan topik penelitian. Bahan hukum tertier yakni bahan yang memberikan penjelasan terhadap bahan hukum primer dan bahan hukum sekunder contohnya adalah kamus, kamus hukum dan ensiklopedia hukum.

Tahapan penelitian dimulai dengan melakukan studi dokumen terlebih dahulu, dilanjutkan dengan menggunakan penelitian kepustakaan lainnya dan wawancara dengan beberapa narasumber. Dari sudut tipologi penelitian ini termasuk penelitian yuridis normatif dengan bahan-bahan hukum yang di gunakan sesuai penjelasan yang telah dikemukakan terdahulu.

Analisis data dalam penelitian ini menggunakan metode analisis kualitatif, dalam hal ini mengkaji secara mendalam bahan hukum yang ada kemudian digabungkan dengan bahan hukum yang lain, lalu dipadukan dengan teori teori yang mendukung dan selanjutnya ditarik kesimpulan secara deduktif.

\section{Hasil dan Pembahasan}

Pelaksanaan Upaya Paksa Penahanan Terhadap Tersangka

Berdasarkan keseluruhan ketentuan tentang penahanan, pembentuk undang-undang memberikan perhatian pada empat hal: 1 . 
lamanya waktu penahanan yang dapat dilakukan; 2. aparat penegak hukum yang berwenang melakukan penahanan; 3 . batas perpanjangan waktu penahanan dan perkecualiannya; 4. hal yang dapat menangguhkan penahanan. Dari keempat hal tersebut diatas (dan sekaligus dapat dianggap sebagai kerangka berfikir pembentuk undangundang) dapat dilihat bahwa cita-cita perlindungan atas harkat dan martabat tersangka atau terdakwa secara formal telah terpenuhi.

Tampaknya jalan yang harus ditempuh masih cukup jauh untuk dapat tercapainya citacita perlindungan dimaksud dalam pelaksanaannya. Hal ini disebabkan perubahan suatu peraturan perundangundangan tidaklah dengan seketika dapat membawa akibat perubahan cara berfikir dan bertindak dari para aparat pelaksananya. Sehubungan dengan Pasal 21 ayat (4) KUHAP, Andi Hamzah pernah mengajukan pertanyaan apakah penahanan dapat dilakukan demi kepentingan keamanan tersangka sendiri (Hamzah, 1985). Menurutnya dalam praktik memang banyak terjadi yang demikian. Delik-delik yang menyangkut kesusilaan sering tersangkanya ditahan misalnya mukah (overspal), padahal ancaman pidana dalam pasal itu dibawah lima tahun dan pasal 284 KUHP tidak disebut dalam Pasal 21 ayat (4) KUHAP. Jika tersangka berada di luar tahanan dikhawatirkan keselamatan jiwanya.

Dengan melihat dan menerapkan teori atau syarat penahanan terdapat syarat subyektif di dalam melakukan penahanan yang tergantung pada orang yang memerintahkan penahanan tadi, apakah syarat itu ada atau tidak syarat subyektif, yaitu karena syarat tersebut diuji ada atau tidak oleh orang lain. Apabila dihubungkan antara dua syarat tersebut dengan syarat penahanan yang tercantum dalam KUHAP, maka yang merupakan syarat subyektif adalah Pasal 21 ayat (1) KUHAP, yakni: (Dewantara, 1987): "1. tersangka atau terdakwa diduga keras melakukan tindak pidana;

a. berdasarkan bukti yang cukup;

b. dalam hal adanya keadaan yang menimbulkan kekhawatiran bahwa tersangka atau terdakwa:

- akan melarikan diri, bukti, dan

- merusak atau menghilangkan barang

- mengulangi tindak pidana."
Syarat obyektif adalah syarat penahanan yang tercantum dalam Pasal 21 ayat (4) KUHAP. Sebelum memasuki tahap keempat proses penyelesaian perkara pidana, terlebih dahulu perlu dikemukakan adanya suatu lembaga baru dalam sejarah sistem peradilan pidana Indonesia, halmana tidak dikenal semasa HIR, yaitu praperadilan. Praperadilan ini merupakan kewenangan Pengadilan Negeri untuk memeriksa dan memutus sesuai dengan ketentuan yang diatur dalam ketentuan undangundang ini tentang:

a) sah atau tidaknya penangkapan, penahanan, penghentian penyidikan atau penghentian penuntutan;

b) ganti kerugian dan/atau rehabilitasi bagi seorang yang perkara pidananya dihentikan pada tingkat penyidikan atau penuntutan (Pasal 77 KUHAP). Berlainan dengan pemeriksaan di muka sidang pengadilan pada umumnya, praperadilan dilakukan oleh hakim tunggal.

Apabila melihat kedudukan praperadilan ini dalam struktur mekanisme peradilan pidana sebagaimana diatur dalam KUHAP, lembaga ini bersifat "accidental" dalam arti baru ada jika ada permintaan dari tersangka, keluarganya, atau kuasanya kepada Ketua Pengadilan Negeri (Pasal 79 KUHAP). Dan itupun jika permohonan yang bersangkutan tidak ditolak oleh Ketua Pengadilan Negeri.

Diundangkannya Undang-undang Nomor 8 Tahun 1981 tentang KUHAP sebagai Pengganti HIR, perhatian terhadap hak asasi manusia di Indonesia dijunjung tinggi, karena seseorang yang dianggap telah melanggar hukum tidak lagi diperlakukan sebagai obyek semata melainkan harkatnya sebagai manusia (subyek) sangat diperhatikan sehingga proses beracara yang menangani pelanggar hukum dirasakan lebih manusiawi, sesuai dengan asas didalam hukum semua manusia di mata hukum diperlakukan sama tanpa kecuali.

Penjatuhan sanksi pidana kepada pelaku kejahatan diharapkan memberikan pencegahan kepada masyarakat dan pelaku sendiri untuk tidak berbuat kejahatan kembali, namun tujuan ini terkadang mengalami kegagalan sehingga terkadang pelaku justru menjadi residivis dan masyarakat sendiri dapat meniru untuk melakukan kejahatan. Hal ini juga karena penerapan sanksi pidana tidak melihat akar persoalan kejahatan yang sebenarnya. Oleh karena itu dibutuhkan pendekatan sosial disamping penerapan sanksi pidana. 
Penahanan dalam kaitannya dengan penerapan prinsip proses hukum yang adil adalah disamping untuk pembatasan ruang lingkup pembahasan juga karena mengingat walaupun penangkapan juga pengekangan terhadap kebebasan manusia tetapi jangka waktunya maksimum hanya satu hari, sedangkan penahanan dalam jangka waktu mencapai 400 hari bahkan dapat mencapai 700 hari dalam Pasal 29 KUHAP, sehingga dapat dipandang sebagai kewajiban warga Lex Crimen Vol. III/No. 4/Ags-Nov/2014 107 negara untuk membantu pengamanan dalam negeri.

Pelaksanaan upaya paksa penahanan bukan hal yang mudah penanganannya, karena berkaitan dengan kebebasan seseorang, yang berarti pula akan menyentuh hak-hak asasi manusia. KUHAP telah mengatur tentang penahanan, namun di dalam pelaksanaannya tidaklah semudah yang diperkirakan. Pelaksanaan penahanan tidak mudah karena bersinggungan dengan hak kebebasan/kemerdekaan sebagai hak asasi manusia yang harus dihormati. Penahanan seharusnya dilakukan jika sangat diperlukan, sebab kekeliruan melakukan penahanan akan berakibat pada tuduhan pelanggaran hak asasi manusia dan dapat dituntut melalui praperadilan ataupun pembayaran ganti kerugian. Hanya karena untuk kepentingan penegakan hukum, hakhak tersangka/terdakwa dengan sangat terpaksa dikorbankan, setidak-tidaknya untuk sementara waktu (Prakoso, 1985).

Penahanan adalah penempatan tersangka atau terdakwa di tempat tertentu oleh penyidik atau penuntut umum atau hakim dengan penetapannya dalam hal serta menurut cara yang diatur dalam KUHAP (Pasat 1 butir 21 KUHAP). Berdasarkan Pasal 1 butir 21 KUHAP dapat diketahui bahwa yang berhak untuk melakukan penahanan adalah penyidik, penuntut umum dan hakim (pada pengadilan negeri, pengadilan tinggi, mahkamah agung). Di samping memberikan kewenangan untuk melakukan penahanan, Pasal 7 ayat (1) huruf $j$ KUHAP masih memberi wewenang kepada penyidik untuk melakukan tindakan lain menurut hukum yang bertanggungjawab. Pasal 7 ayat (1) huruf $\mathrm{j}$ KUHAP seolah-olah memberi keleluasaan bagi penyidik untuk bertindak sesuai kehendaknya dengan anggapan bahwa apa yang dilakukannya merupakan tindakan keharusan dan masih selaras dengan kewajibannya.
Penahanan dilakukan untuk kepentingan proses pemeriksaan atau penyelesaian perkara. Oleh karena itu maka: (1). Penyidik atau penyidik pembantu atas pelimpahan wewenang dari penyidik melakukan penahanan untuk kepentingan penyidikan. (2). Penuntut umum melakukan penahanan untuk kepentingan penuntutan. (3). Hakim melakukan penahanan untuk kepentingan pemeriksaan perkara di pengadilan.

Perintah penahanan atau penahanan lanjutan (dalam hal penahanan diperpanjang) dilakukan terhadap seorang tersangka atau terdakwa yang diduga keras melakukan tindak pidana berdasarkan bukti yang cukup, apabila dikhawatirkan bahwa tersangka atau terdakwa akan melarikan diri, merusak atau menghilangkan barang bukti dan atau mengulangi tindak pidana. Alasan untuk melakukan penahanan adalah adanya kekhawatiran dari aparat penegak hukum yang berhak untuk menahan. Apabila pejabat yang bersangkutan (penyidik, penuntut umum, hakim) tidak khawatir bahwa tersangka atau terdakwa akan melarikan diri, merusak atau menghilangkan barang bukti atau mengulangi tindak pidana, maka tersangka/terdakwa tidak perlu ditahan. Pemeriksaan berlangsung tanpa penahanan, dan tersangka atau terdakwa akan dipanggil apabila diperlukan untuk kepentingan pemeriksaan.

\section{Persyaratan Penahanan Sebagai Upaya Paksa Menurut KUHAP \\ Dasar hukum atau dasar obyektif menunjuk kepada tindak pidana yang menjadi obyek atau jenis tindak pidana yang dapat dikenakan penahanan, yaitu tindak pidana yang dipersangkakan diancam dengan pidana penjara lima tahun atau lebih, atau tindak pidana yang ditunjuk dalam Pasa121 ayat (4) huruf $b$ KUHAP.}

Dasar kepentingan/subyektif merujuk kepada kepentingan aparat penegak hukum untuk melakukan penahanan, yaitu untuk kepentingan pemeriksaan. Sesuai dengan tujuan penahanan, apabila pemeriksaan di tingkat penyidikan telah selesai, maka berkas (Berita Acara Penyidikannya harus segera dilimpahkan kepada kejaksaan negeri (penuntut umum), demikian seterusnya pelimpahan perkara dari penuntut umum ke pengadilan serta pemeriksaan dalam persidangan di pengadilan. Dengan demikian masa penahanan dan/atau perpanjangan penahanan di tingkat penyidikan 
yang belum dijalaninya dengan sendirinya tidak perlu dijalani lagi setelah Berita Acara Penyidikan yang telah dinyatakan lengkap dilimpahkan kepada kejaksaan. Penahanan di tingkat penyidikan dengan sendirinya berakhir, demikian seterusnya di tingkat penuntutan dan pemeriksaan di pengadilan. Selanjutnya, apabila jangka waktu penahanan atau perpanjangan penahanannya telah berakhir, sedangkan pemeriksaannya belum selesai maka si tersangka/terdakwa derni hukum harus dibebaskan dari penahanan. Dibebaskan dari penahanan bukan berarti perkaranya dihentikan, melainkan tetap diproses, akan tetapi si tersangka/terdakwa tidak boleh ditahan lagi pada tingkat pemeriksaan yang bersangkutan. Penyidik, penuntut umum dan hakim sebagai subyek pelaku penahanan, melakukan penahanan terhadap tersangka/terdakwa karena dikhawatirkan bahwa tersangka/terdakwa akan melarikan diri, merusak atau menghilangkan barang bukti dan/atau mengulangi tindak pidana.

Ada tiga macam jenis penahanan, yaitu penahanan rumah tahanan negara (Rutan), penahanan rumah, dan penahanan kota. Penentuan jenis penahanan yang akan ditetapkan kepada seorang tersangka atau terdakwa ditentukan oleh pejabat yang bersangkutan sesuai dengan tingkat pemeriksaan. Demikian juga mengenai pengalihan jenis penahanan dari jenis penahanan yang satu ke jenis penahanan yang lain, atau mengubah status penahanan, dari status ditahan menjadi dibebaskan dari penahanan (tidak ditahan), atau sebaliknya. Seorang tersangka/terdakwa ditahan di tingkat penyidikan akan tetapi tidak ditahan di tingkat penuntutan atau pengadilan, dan sebaliknya. Hal ini sejalan juga dengan alasan dilakukannya penahanan, yaitu adanya 'kekhawatiran' bahwa tersangka/terdakwa akan melarikan diri, menghilangkan atau merusak barang bukti, dan/atau mengulangi tindak pidana. Atas dasar hal tersebut, dapat saja terjadi kekhawatiran itu ada pada penyidik, akan tetapi penuntut umum tidak mengkhawatirkannya, sehingga pada saat penyidikan tersangka ditahan akan tetapi setelah berkasnya dan tersangka dilimpahkan ke kejaksaan negeri (penuntut umum), si tersangka/terdakwa tidak dikenakan penahanan. Dapat juga terjadi bahwa pada awalnya penyidik khawatir bahwa tersangka akan melarikan diri dan/ atau merusak/menghilangkan barang bukti, dan/atau akan mengulangi tindak pidana sehingga dikenakan penahanan, akan tetapi dalam perjalanan pemeriksaan kekhawatiran itu menjadi hilang, sehingga si tersangka tidak ditahan lagi, demikian juga sebaliknya pada setiap tingkat pemeriksaan.

Setelah KUHAP berusia lebih dari dua dasawarsa, banyak hal telah terjadi, terutama yang berkenaan dengan tindakan penahanan yang tidak sesuai dengan prinsip proses hukum yang adil yang mengakibatkan pelanggaran hak asasi manusia yang dilakukan aparat penegak hukum dalam pelaksanaan penahanan. perlunya upaya untuk lebih meningkatkan pemahaman dan penerapan prinsip proses hukum yang adil sehingga tidak akan menimbulkan jatuhnya korban-korban baru tidak saja sekedar korban dari kejahatan tetapi juga korban peradilan. Sahetapy menulis bahwa korban yang dewasa ini begitu hangat dikasak kusukkan secara terselubung adalah korban peradilan, yang dimaksudkan peradilan di sini yaitu mulai dari proses pemeriksaan dan atau penahanan di kepolisian sampai diserahkan kepada Lembaga Pemasyarakatan. Oleh karena itu tidak berlebihan bila Perserikatan Bangsa-Bangsa (PBB) menaruh perhatian serius terhadap masalah penahanan ini khususnya Prisoners under Arrest or A Waiting Trial atau tahanan yang sedang menunggu pemeriksaan di depan pengadilan.

Sebagai upaya paksa, penangkapan dan/atau penahanan dilakukan jika tidak ada lagi upaya lain yang dapat digunakan untuk mengatasi kondisi yang sedang dihadapi guna kepentingan pemeriksaan. Kekhawatiran pejabat yang bersangkutan sebagai alasan untuk melakukan upaya paksa penahanan menjadi tidak berdasar ketika adanya jaminan dari berbagai pihak, suami/isteri, penasihat hukum, tokoh masyarakat, tokoh nasional atau pihak lain bagi tersangka/terdakwa bagi tersangka/terdakwa, tentu dengan memperhatikan setiap kondisi secara kasuistis.

\section{Simpulan}

Pelaksanaan penahanan membuka kemungkinan yang lebih luas untuk terjadinya penyalahgunaan kekuasaan baik karena kurangnya keterampilan dan pemahaman aparat maupun karena kelalaian. Di samping karena kurangnya keterampilan dan pemahaman akan hak asasi manusia sebagai inti dari prinsip proses hukum yang adil, terjadinya berbagai penyimpangan dalam praktik pelaksanaan 
penahanan juga karena undang-undang tidak tuntas mengaturnya sampai mendetail, sehingga dalam banyak hal diserahkan kepada praktik dan kebiasaan. Yang semestinya tidak boleh menyimpang dari rumusan Undang-undang dan prinsip perlindungan hak asasi manusia yang dijunjung tinggi oleh KUHAP.

KUHAP No. 8 Tahun 1981 telah menentukan berbagai persyaratan pelaksanaan penahanan agar tidak terjadi penyalahgunaan wewenang dan penahanan maupun kesalahan dalam melaksanakan penahanan, baik kesalahan dalam prosedur terlebihlebih kesalahan yang sifatnya "human error" yang akan menimbulkan kerugian moril dan materil baik bagi diri pribadi maupun keluarga tersangka apalagi bila akhirnya tidak terbukti bersalah atau kesalahannya tidak sepadan dengan penderitaan yang telah dialaminya.

\section{Referensi}

Asshiddiqie, J. (2006). Konstitusi dan
Konstitusionalisme Indonesia. Jakarta: Konstitusi Press.

Dewantara, N. A. (1987). Masalah Penangkapan, Penahanan, Penggeledahan, Penyitaan, dan Pemeriksaan Surat di dalam Proses Acara Pidana. Jakarta: Aksara Persada Indonesia.

Hamzah, A. (1985). Pengantar Hukum Acara Pidana. Jakarta: Ghalia Indonesia.

Karjadi. (1981). Kitab Undang-Undang Hukum Acara Pidana. Jakarta: Politea. Prakoso, D. (1985). Eksistensi Jaksa di Tengah-tengah Masyarakat. Jakarta: Ghalia Indonesia.

Soekanto, S. (1986). Pengantar Penelitian Hukum. Jakarta: UI Press.

Soemantri, S. (1992). Bunga Rampai Hukum Tata Negara Indonesia. Bandung: Alumni. 